\title{
Identification and Ranking of Cloud-based Applications in E-learning of Afghanistan: A Case of Public Universities
}

\author{
Sayed Zabihullah Musawi ${ }^{1}$ and Jawid Ahmad Baktash ${ }^{2}$ \\ ${ }^{1}$ Kunduz University, Kunduz, Afghanistan \\ ${ }^{2}$ Kabul University, Kabul, Afghanistan \\ sayedzabimusawi@kundoz.edu.af
}

\section{ARTICLE HISTORY \\ Received : 24 December 2020 \\ Revised : 19 January 2021 \\ Accepted : 8 March 2021}

\section{KEYWORDS \\ E-learning \\ Cloud-based Application \\ Moodle \\ E-learning in Afghanistan \\ Google Classroom}

\begin{abstract}
Cloud-based Applications are suitable tools in the E-learning system, and they bring the most facilities in E-learning due to availability and on-demand self-services. During Covid19 lockdown, while presential learning stopped and E-learning started. The Ministry of Higher Education has begun E-learning in public and private universities. Therefore, Afghanistan's universities used Cloud-based Apps in E-learning, but these Apps are not identifying and ranking in the E-learning of Afghanistan. This study aims to identify and rank the Cloud-based Apps in terms of usefulness and effectiveness in E-learning using state-of-the-art, and its usage in public universities of Afghanistan. To get an accurate answer to the defined questions, mixed research was used. Therefore, an online questionnaire was distributed randomly to six public universities in six different parts of Afghanistan. The respondents were divided into two categories (lecturers and students) and asked to respond to Cloud-based Apps usage and effectiveness in E-learning. The responses were analysed using Chi-Square Tests. The result showed the most, low, and lowest useful Cloud-based Apps in E-learning. In conclusion, the research finding showed that Google Classroom was the most LMS, WhatsApp was the most mobile instant messaging, Gmail was the most E-mail server and Skype was the most video conferencing Cloud-based Apps

in E-learning in most public universities of Afghanistan.
\end{abstract}

\section{Introduction}

Due to the Quarantine of the Corona Virus E-learning was the only solutions for learning all over the globe, Elearning with the terms of distance learning, network-based learning, computer-based learning, web-based learning (Radha et al., 2020), computer-based learning have common meanings and concepts (Mirzaei \& Shabani Nia, 2013; Zhang et al., 2004). Furthermore, Electronic education can be defined as follows: Electronic education is a set of educational activities that are done using electronic tools (Kundu, 2021) such as audio, video, computer, network and virtual, and so on. In other words, all programs that lead to learning through computer networks, especially the Internet (Butola, 2021) are called E-learning. Thus, E-learning is a tool that facilitates the learning process (Babaie, 2015; Peroz, 2015; Sağlam, 2019).

At present, most countries are migrated from presential learning method to E-learning (Affouneh et al., 2020) due to its effectiveness factors in pandemic condition (Al Kodri, 2020), and it has changed the process of learning by using various Apps. The use of E-mail, free video conferencing Apps, MIM Apps, free file-sharing programs are a new chapter in distance learning that is common in the sense of E-learning. The use of these technologies has eliminated distances and made teaching more effective than ever; Because E-learning despite the traditional method is not committed to prepare the education at the same time and place for the learner and teacher (Abed, 2019). On the other hand, with the use of E-learning, it is possible to learn every time and everywhere (Aparicio et al., 2017; Salih \& Taniwall, 2020). Therefore, during the Covid-19 outbreak Ministry of Higher Education proposed E-learning instead of presential learning, and Afghanistan public's universities had extreme development in terms of E-learning implementation in a short time. The E-learning deployment started with the assist of Google Classroom, and continue with HELMS in public and private universities of Afghanistan. Besides, mentioned LMSs some Cloud-based Apps were useful in E-learning, but not identify and rank because of lack of the previous deployment. Thus, the study effort is to identify and rank the most Cloud-based Apps in E-learning in public universities of Afghanistan.

\section{Literature Review}

\subsection{Cloud-based Application}

Cloud computing is a computational method that is automatically configurable and most of its resources are virtualized and available in the form of services via the Internet (Song, 2020). Therefore, Cloud services are accessible via web applications, and web applications are the most component of Cloud computing (M. Ali et al., 2015; Radha et al., 2020) Nowadays, the emergence of the Cloud 
phenomenon or Cloud computing technology in the world of ICT has played an effective role in advancing the process of E-learning (Sağlam, 2019); Because today, most E-learning technologies and tools work based on Cloud computing, and Cloud computing provides infrastructure, applications, and storage space to institutions and institutions that provide Elearning; therefore lots of organizations are deploying Cloud computing service because of its business support (Naveed et al., 2019) access from different locations (Ali, 2020; Burke, 2021). The main Cloud computing technologies and tools include E-mail programs (e.g., Gmail, Yahoo, AOL), messaging and data sharing programs (e.g., WhatsApp, Viber), video conferencing (e.g., Zoom, Microsoft Teams) and LMS (e.g., Moodle, Google Classroom, and Blackboard) considered in this study. These tools are the most useful in some countries (Radha et al., 2020).

\subsection{Learning in Afghanistan}

Education is of particular importance in the sacred religion of Islam; The Prophet of Islam said: " Seek knowledge from the cradle to the grave" Elsewhere, he said, "Look for science, even if it's in China." These statements are examples of valuing knowledge and the importance of knowledge. Afghanistan, as an Islamic country, has given special value to knowledge and education, according to the Holy Prophet of Islam. Therefore, Education in Afghanistan has a long history; In the past and present, education has been done through mosques with the teaching of the Qur'an and the principles of religion in small areas and villages, then education was introduced using schools and universities.

Formal learning with the assist of schools and universities was the second phase of learning in Afghanistan. Therefore, the first boy school by the name of Habibia High School was established in 1903, and the girls' school by the name of Asmat establish in 1928 in Kabul (Sultani, 2001). Kabul University was the first place for higher education that was established in 1932 in Kabul. Thus, the mentioned schools and universities were the first official places in learning in Afghanistan, yet today Afghanistan has 39 public and 128 private universities (https://mohe.gov.af/).

\subsection{E-learning in Afghanistan}

Afghanistan universities interconnected to International universities since the IT Center of Kabul University (ITCK) establishment in March 2003, and after the establishment of ITCK students and lecturers could access the Internet, web accessing, and online chatting with friends (Peroz, 2015). Therefore, accessing and finding the chance to chat with their friends after several years of war could be a dream for every Afghan citizen especially for students, lecturers, and researchers as well. Since 2005 a lot of international universities and organizations have been tried to establish the E-learning platform to support teaching and learning in Afghanistan's universities (Peroz, 2015). Due to this effort and continuous Afghanistan's International partner support, today every Afghanistan university is interconnected with fiber optic and has already access to the Internet. Kunduz
University which is located in the north-east of Afghanistan has $40 \mathrm{Mbps}$ bandwidth of the Internet. It could be an example of improvement and success from 2003 to 2020 for Afghanistan.

Nowadays, due to the outbreak of Coronavirus most education centers barred (Alqahtani \& Rajkhan, 2020), therefore, governments and universities are tried to use Elearning services (Arshad Khan et al., 2021; Cicha et al., 2021; Kaisara \& Bwalya, 2021) and platforms so that citizens are not deprived of education (Gurme, 2019). With this in mind, the Afghan government prioritizes E-learning over its programs and strongly supports it. Currently, Afghanistan's universities implemented E-learning in two steps. In the first step, the Ministry of Higher Education with a lack of existence system implemented the E-learning with the assist of Google Classroom and continue the lesson during the COVID-19 lockdown. In the second step, the MoHE with the collaboration of Kabul Polytechnic University developed the HELMS (Higher Education Learning Management System) to implement and manage Elearning in public universities. Implementing E-learning without considering previous planning cannot be without flaws and barriers as (Hannache-Heurteloup \& Moustaghfir, 2020) and (Aldulaimi et al., 2021) pointed, especially in a country like Afghanistan that has a lot of challenges including lack of electricity, disconnect telecommunication networks, lack of ICT infrastructures (Musawi et al., 2020), or it might have some considered positive effect during Covid-19 outbreak on society (Fatani et al., 2021; Neelavathy, 2020).

\section{Method}

This study tried to identify and rank Cloud-based Apps in E-learning of public universities of Afghanistan using state-of-the-art, and a mixed approach was employed for this study. Therefore, the sources of collected data were an online questionnaire and open-ended questions. The questionnaire was structured into two categories, four demographic questions, and four main questions. The questionnaire was developed basis on four main factors identified through discussions with students, lecturers, and depth literature review. Furthermore, at the end of the questionnaire, we formulated two open-ended questions to collect the relevant issues related to E-learning that may not consider in questionnaire categories.

The study population was bachelor's students and lecturers from public universities of Afghanistan. The participants were varied in terms of fields including Computer Science, Psychology, Sociology, Chemistry, Economy, Biology as well. These fields were selected randomly, and the fields of the study had not affected in data analysis. After sharing an online questionnaire, we gathered 128 responses from $n=28$ females and $n=68$ males from six different universities of Afghanistan like Shaheed Rabani Education University, Kunduz University, Takhar University, Samangan Institute of Higher Education, Ghor Institute of Higher Education, Parwan University as well. 
Among 128 responded questions, 96 responses were considered useful for analysis, and the Chi-Square test was applied for data analysis in SPSSv26.

\section{Results}

The collected data from the questionnaire were in two sections, demographic questions, and main questions. Furthermore, two open-ended questions were as well. Therefore, after valuing into each question the Chi-SquareTest employed. Thus, the research results are illustrated in Figures 1 to 7.

The research was designed to content different categories of participations including location, six and occupation. Therefore, gender, job and universities of participation were considered in this research.

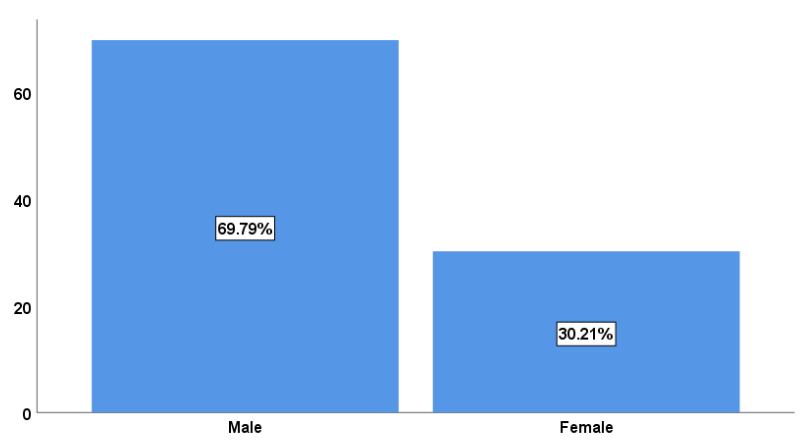

Figure 1. Participants' Gender
In this survey, $(69.79 \%)$ were male and $(30.21 \%)$ were female. Therefore, this study shows that female participation was less than males due to personal barriers (Aldulaimi et al., 2021; Hannache-Heurteloup \& Moustaghfir, 2020).

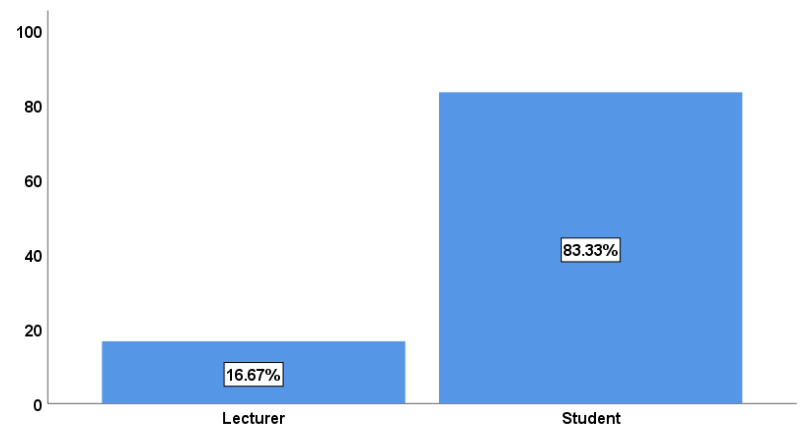

Figure 2. Participants' Job

The illustrated figure shows that $(16.67 \%)$ of participants were lecturers and $(83.33 \%)$ were students from six different universities from six different parts of Afghanistan. Therefore, lecturers and students had continued the education even with a shortage of ICT tools, and this is in line with what Musawi et al. (2020) stated.

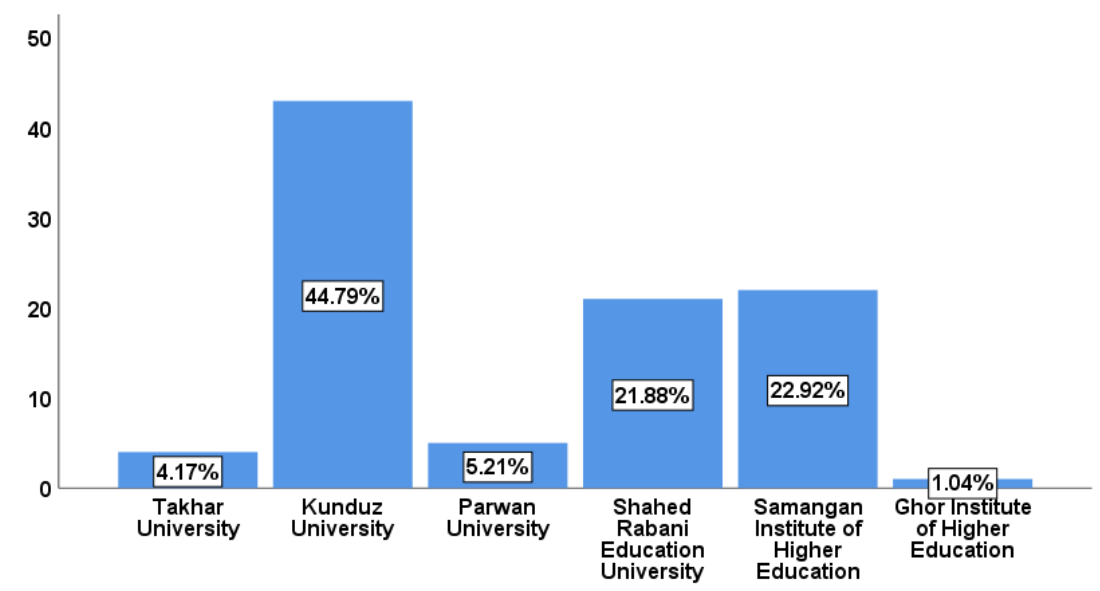

Figure 3. Participants' Universities

The illustrated figure shows surveyed universities that $(44.79 \%)$ were from Kunduz, $(22.92 \%)$ from Samangan Institute of Higher Education, (21.88\%) from Shaheed Rabani Education University, (5.21\%) from Parwan
University, (4.17\%) from Takhar University and (1\%) from Ghor Institute of Higher Education. The study result shows, although, the E-learning started due to Covid-19 outbreak at hard condition, the universities participation were good. 


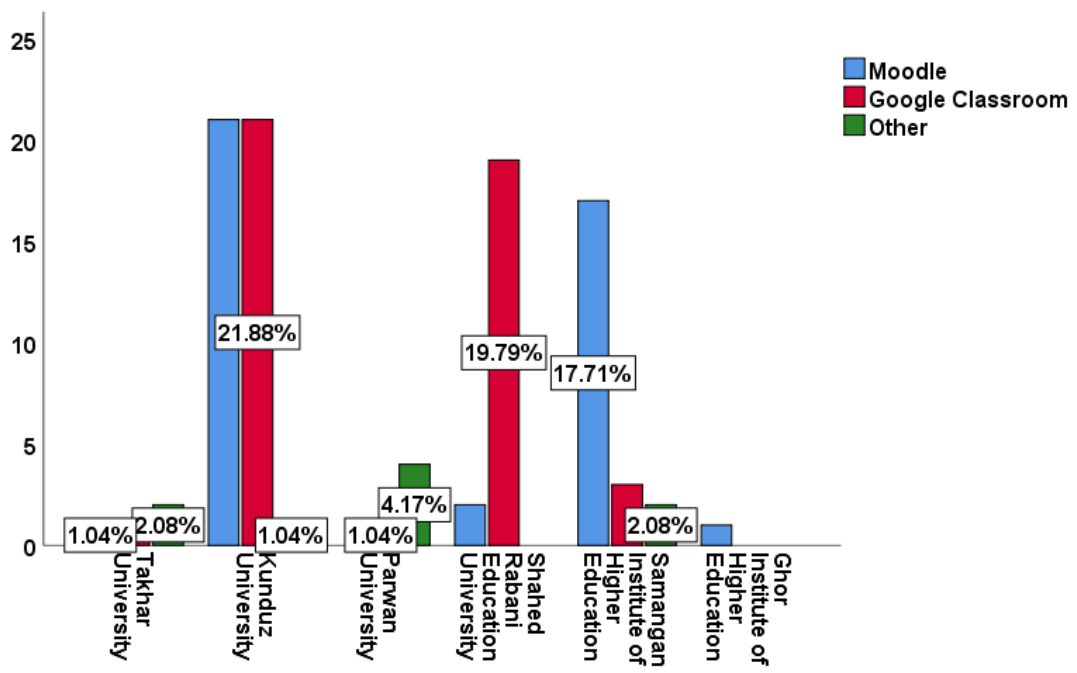

Figure 4. Which E-learning system do you use?

As shown in the Figure 4, Google Classroom with $(46.88 \%)$ and Moodle with $(43.75 \%)$ use are the useful systems in E-learning in Afghanistan. Besides, (9.38\%) Elearning users use another system. According to the study open-ended questions, the reasons for using Google Classroom more than Moodle were the heaviness of Moodle, and it has had needed more Internet speed.

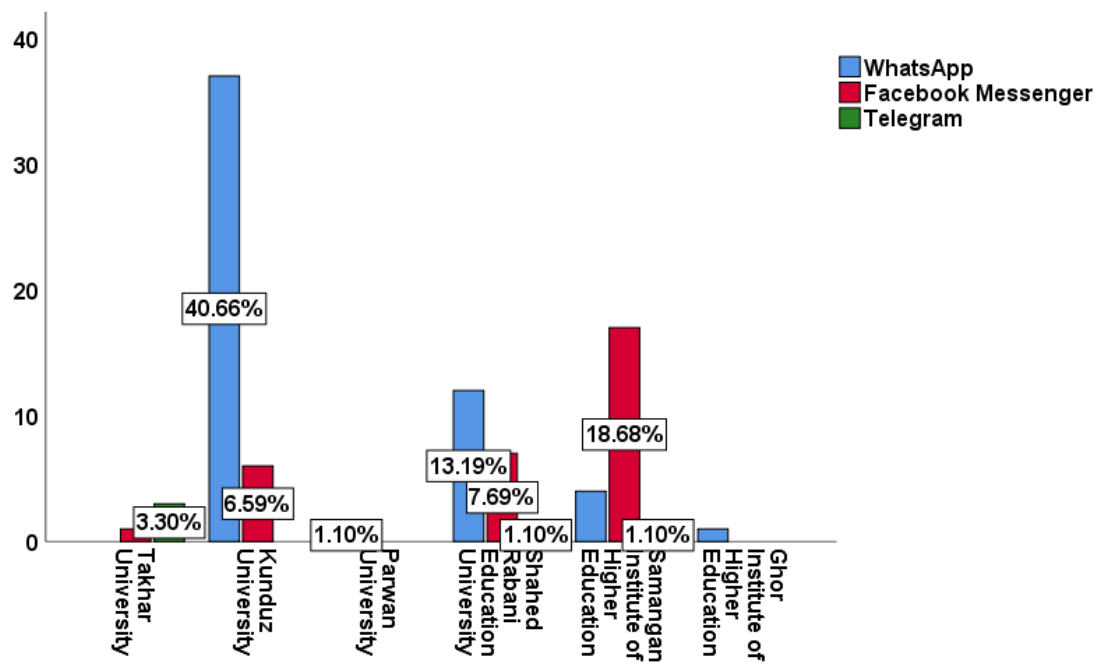

Figure 5. Which Cloud-based instant apps do you use in E-learning?

Figure 5 shows that WhatsApp with (60.42\%), Facebook Messenger with (34.38\%), and Telegram with (5.21\%) were the most useful instant messaging App respectively.
WhatsApp specifically is the most popular, especially in Kunduz University, although one other university preferred to use Facebook Messenger. 


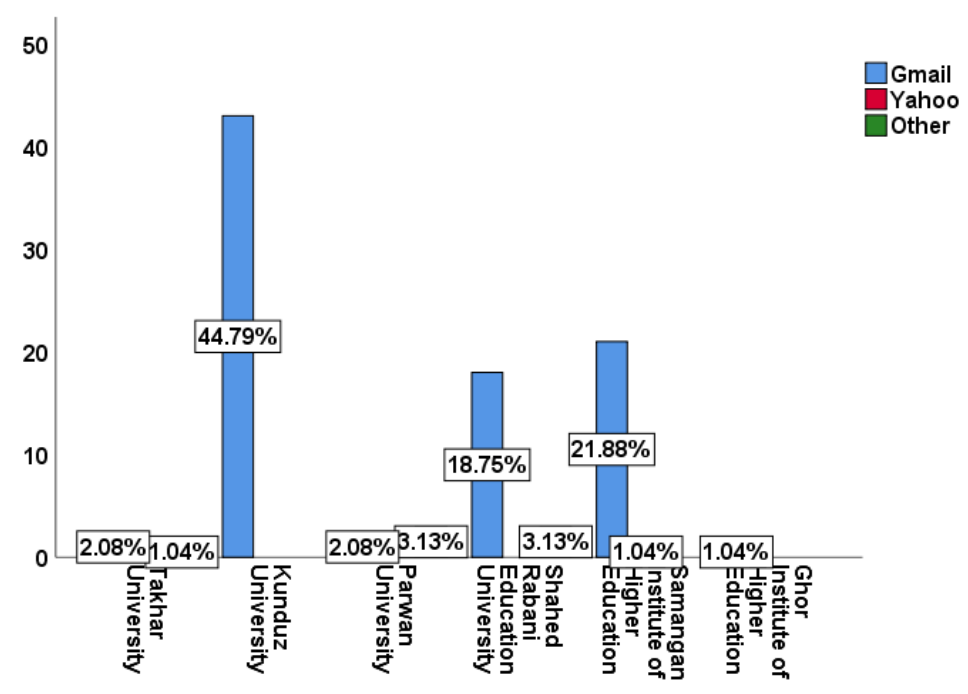

Figure 6. Which public e-mail server do you use in academic communications?

According to the survey, Gmail (88.54\%), Yahoo (2.1\%) were useful E-mail servers for E-learning purposes, but $(9.4 \%)$ used other E-mail servers, and it might be a university
E-mail server. Because public E-mail servers have the most used due to the lack of academic E-mail servers in public universities of Afghanistan.

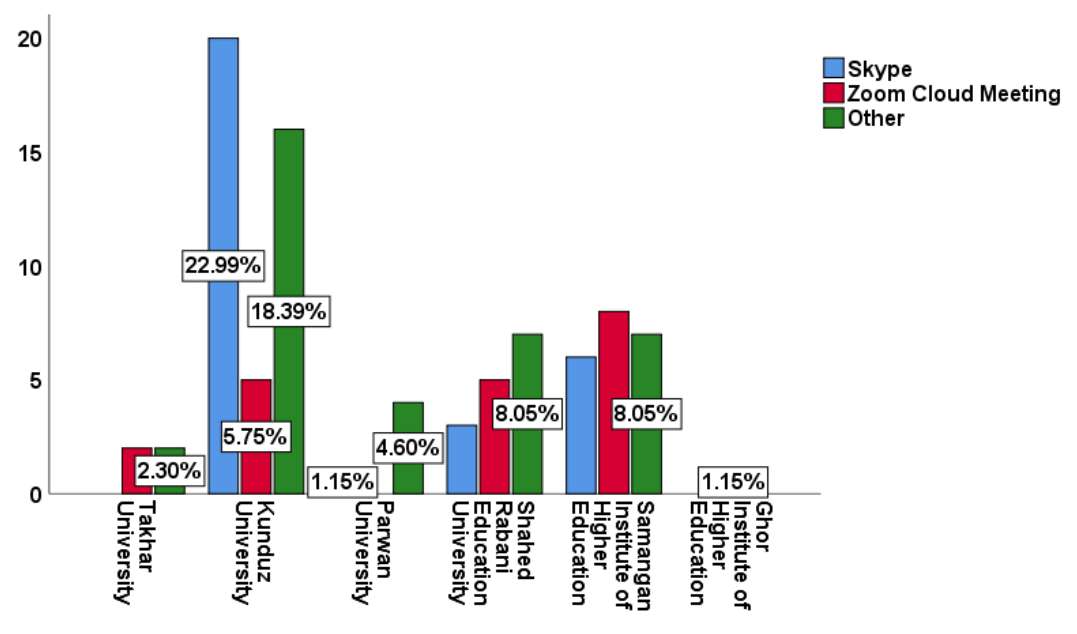

Figure 7. Which Cloud-based app do you use for video conferencing?

The illustrated figure showed that Skype with (40.63\%), Zoom (34.38\%), Microsoft Teams (3.1\%) were the most useful Apps in Afghanistan's E-learning system, besides (21.9\%) were used other Apps for video conferencing purposes.

\section{Discussion}

The novel virus (Covid-19) breakdown has caused to stop face-to-face learning all over the world. Therefore, online learning with the assist of Cloud-based Applications was the only option that most countries selected for continuing the learning in schools and universities. Thus, Afghanistan like other countries tried to implement E-learning in public universities. Nowadays, most of the public and some private universities implemented E-learning to continue learning for students. The implementation of E-learning before preplanning and lack of infrastructure and systems have caused that every university, lecturer, and student to use different tools to do the learning. Therefore, Cloud-based Applications were the most accessible tools in Afghanistan because of free and on-demand self-services.

\subsection{Learning Management Systems}


E-learning like E-government and other E-system need some type of infrastructure and tools. Therefore, besides some public LMSs including Google Classroom, DOKEOS, Academic Suite, Blackboard, ATutor, and Moodle (Aldulaimi et al., 2021) some of the countries and universities developed the owned system to manage the Elearning system. Based on this research, Google Classroom was the first tools for E-learning purposes at lack of localized LMS in Afghanistan, moreover, after the implementation of Google Classroom, the Ministry of Higher Education with the technical assistance of Kabul Polytechnic University developed the HELMS (Higher Education Learning Management System) in Afghanistan. Therefore, Google Classroom and HELMS were two useful LMSs in Elearning, but Google Classroom was the most useful LMS than HELMS in E-learning in public universities of Afghanistan due to heaviness of HELSM.

\subsection{Cloud-based Instant Messaging Apps}

There have been many studies in Mobile Instant Messaging (MIM) and Cloud-based Apps in terms of Elearning. Moreover, most studies focused on the role and the effectiveness of MIM especially WhatsApp in specific fields such as ELT for EFL (Arifani, 2019; Jafari \& Chalak, 2016; Kartal, 2019; Minalla, 2018; Ta'amneh, 2017) and Computer Science due to the leaner's familiarity in the English Language. According to Jafari and Chalak (2016), WhatsApp has a positive effect on English vocabulary learning among Iranian EFL learners in comparison to traditional learning, and (Suadi, 2021) stated that WhatsApp has a positive effect on ELT for EFL learning skills. In another word, according to the research open-ended questions, lack of English literacy was a big barrier for Elearning deployment. Although this study did not obtain specific fields, the research finding shows that WhatsApp with $60.4 \%$ ) usage has been the most useful MIM in comparison to Facebook Messenger, Telegram in all fields of study in public universities of Afghanistan.

\subsection{Cloud-based E-mail Servers}

E-mail servers are the most useful tools in all types of communication, especially in academic affairs. At present most of the public universities did not have academic E-mail addresses which caused most lecturers are using public Email servers. According to our research findings, public Email servers are mostly used in material sharing due to Cloud massive file sharing futures (Gmail server preparing 15GB in Google Drive and Yahoo mail server preparing 5GB free space in One Drive for data storing in Cloud-space). Therefore, these Apps have been useful in E-learning, and Gmail with $(88.5 \%)$, Yahoo mail $(2.1 \%)$ were the most useful E-mail servers for E-learning and academic purposes.

\subsection{Cloud-based Videoconferencing Apps}

Cloud-based and video-conferring Apps have had a significant role in E-learning due to preparing a face-to-face interaction. Real-time communication among lecturers and students is required for teaching. Real-time interaction may be part of education in some types of fields and has impressive benefits in educations. According to (Suadi, 2021) using Zoom in E-learning increased the students' confidence feeling in practicing English. Therefore, these video-conferencing Apps were also useful in E-learning in Afghanistan, but the study didn't focus on specific fields. Generally, Skype with (40.6\%), Zoom (34.4\%), and Microsoft Teams with $(3.1 \%)$ were the most useful videoconferencing Apps in E-learning in Afghanistan.

\section{Conclusion}

During the Covid-19 outbreak, E-learning was the most significant issue in universities of Afghanistan. Therefore, the study aimed to identify and rank the Cloud-based Apps in E-learning in public universities. This research used a mixed-method. Besides, demographic questions the survey questions were categorised into two sections, four (LMSs, MIM tools, Mail servers, and Video Conferencing tools) and two open-ended questions. The participants were lecturers and students, but the participation of males was more than females in this study. Thus, based on the research finding. At first, Google Classroom was the most useful LMS. Second, WhatsApp and Facebook Messenger were the most useful mobile instant messaging Apps. Third, Gmail was the most substantial E-mail server. Finally, Skype and Zoom were the identified Cloud-based Apps in video conferencing in Elearning in public universities of Afghanistan. In conclusion, Google Classroom with $46.9 \%$, WhatsApp with $60.4 \%$, Gmail with $88.5 \%$, and Skype with $40.6 \%$ usage were the most significant Cloud-based video conferencing App in Elearning of Afghanistan.

Based on this conclusion, the mentioned Apps are proposing for education planer to consider in future plans. Moreover, further study is needed to investigate on two following reasons: The effect of each MIM, LMS, Video conferring Apps on enhancing E-learning on specific fields, and the effective factor for using these Apps in E-learning in Afghanistan.

\section{Acknowledgment}

We honestly want to thank the students, lecturers, and board of directors of public universities of Afghanistan for participating and assisting in this study. We believe it could not have been achievable without your extraordinary help.

\section{References}

Abed, E. K. (2019). Electronic Learning and its Benefits in Education. EURASIA Journal of Mathematics, Science and Technology Education, 15(3).

Affouneh, S., Salha, S., \& Khlaif, Z. N. (2020). Designing Quality E-Learning Environments for Emergency Remote Teaching in Coronavirus Crisis. Interdiscip $J$ Virtual Learn Med Sci, 11(2), 1-3. 
Al Kodri, M. N. (2020). The Role of Digital Technology in Sustaining Online Learning during the Pandemic Covid19. UHAMKA International Conference on ELT and CALL, 24-31.

Aldulaimi, S. H., Abdeldayem, M. M., \& Abo Keir, M. Y. (2021). E-Learning in Higher Education and Covid-19 Outbreak: Challenges and Opportunities. An Interdisciplinary Journal, 58(2), 38-43.

Ali, A. (2020). Cloud computing adoption at higher educational institutions in the KSA for Sustainable Development. International Journal of Advanced Computer Science and Applications, 11(3), 413-419. https://doi.org/10.14569/ijacsa.2020.0110352

Ali, M., Khan, S. U., \& Vasilakos, A. V. (2015). Security in cloud computing: Opportunities and challenges. Information Sciences, 305, 357-383. https://doi.org/10.1016/j.ins.2015.01.025

Alqahtani, A. Y., \& Rajkhan, A. A. (2020). E-Learning Critical Success Factors during the COVID-19 Pandemic: A Comprehensive Analysis of E-Learning Managerial Perspectives. Education Sciences, 10(216), $1-16$. https://doi.org/doi:10.3390/educsci10090216

Aparicio, M., Bacao, F., \& Oliveira, T. (2017). Grit in the path to e-learning success. Computers in Human Behavior, 66 , 388-399.

https://doi.org/10.1016/j.chb.2016.10.009

Arifani, Y. (2019). The application of small whatsapp groups and the individual flipped instruction model to boost EFL learners' mastery of collocation. Call-Ej, 20(1), $52-73$.

Arshad Khan, M., Vivek, Kamalun Nabi, M., Khoja, M., \& Tahir, M. (2021). Students' Perception towards ELearning during COVID-19 Pandemic in India: An Empirical Study. Sustainability, 13(57), 2-14.

Babaie, M. (2015). An Introduction to E-Learning (Vol. 3, Issue 2). $\quad$ www.irandoc.ac.ir http://repositorio.unan.edu.ni/2986/1/5624.pdf

Burke, B. (2021). Top Strategic Technology Trends for 2021.

Butola, L. K. (2021). E-learning- A New Trend of Learning in 21st Century During Covid-19 Pandemic. Indian Journal of Forensic Medicine \& Toxicology, 15(1), 422-246.

Cicha, K., Rizun, M., Rutecha, P., \& Strzelecki. (2021). COVID-19 and Higher Education: First-Year Students' Expectations toward Distance Learning
Karina. Sustainability, 13(1889), 2-19. https://doi.org/doi.org/10.3390/ su13041889 Academic

Fatani, O. A., Mijlad, W. K., \& Al-Hakeem, M. M. (2021). Perception and Satisfaction on the Online Teaching in OB/GYN Course during COVID-19. Scholars International Journal of Obstetrics and Gynecology, $4(1), 6-10$.

Gurme, V. M. (2019). Challenges and opportunities facing e-learning for the higher education sector in pune during covid19. International Journal of Scientific Development and Research, 6(2), 2455-2631.

Hannache-Heurteloup, N., \& Moustaghfir, K. (2020). Exploring the barriers to e-learning adoption in higher education: A roadmap for successful implementation. International Journal of Management in Education, 14(2), 159-182. https://doi.org/10.1504/IJMIE.2020.105407

Jafari, S., \& Chalak, A. (2016). The Role of WhatsApp in Teaching Vocabulary to Iranian EFL Learners at Junior High School. English Language Teaching, 9(8), 85. https://doi.org/10.5539/elt.v9n8p85

Kaisara, G., \& Bwalya, K. J. (2021). Investigating the ELearning Challenges Faced by Students during Covid19 in Namibia. International Journal of Higher Education, $\quad 10(1), \quad 308-318$. https://doi.org/doi:10.5430/ijhe.v10n1p308 Accepted:

Kartal, G. (2019). What's up with WhatsApp? A Critical Analysis of Mobile Instant Messaging Research in Language Learning. International Journal of Contemporary Educational Research. https://doi.org/10.33200/ijcer.599138

Kundu, D. K. (2021). E-Learning-Teaching Strategies and Teachers' Stress in Post Covid-19 (D. K. Kundu (ed.)). Madan Sachdeva.

Minalla, A. A. (2018). The Effect of WhatsApp Chat Group in Enhancing EFL Learners' Verbal Interaction outside Classroom Contexts. English Language Teaching, 11(3), https://doi.org/10.5539/elt.v11n3p1

Mirzaei, A., \& Shabani Nia, F. (2013). Review of ELearning Modern Systems. Http://Mediaj.Sums.Ac.Ir/Online, 4(2), 62-74.

Musawi, S. Z., Qasimi, M., \& Mousavi Nizhad, S. M. A. (2020). Obstacles and Opportunities of E-Learning Implementation in Afghanistan: A case of Public Universities. Internation Journal of Advance Research 
and Innovative Ideas In Education, 6(4), 309-314.

Naveed, Q. N., Rafik, M., Mohamed, N., Shaikh, A., Alsayed, A. O., Sanober, S., \& Mohiuddin, K. (2019). Evaluating and Ranking Cloud-Based E-Learning Critical Success Factors ( CSFs ) Using Combinatorial Approach. IEEE Access, 157145-157157. https://doi.org/10.1109/ACCESS.2019.2949044

Neelavathy, M. (2020). Impact of Lockdown on Learning Status of College Students During Covid-19 Pandemic in Madurai District. Aut Aut Research Journal, X1(X1), 329-338.

Peroz, N. (2015). Strategic Framework for the Employment of E-learning Projects in Afghanistan Challenges and Requirements.

Radha, R., Mahalakshmi, K., Kumar, V. S., \& Saravanakumar, A. (2020). E-Learning during Lockdown of Covid-19 Pandemic: A Global Perspective. International Journal of Control and Automation, 13(4), 1088-1099.

Sağlam, M. (2019). Fundamental Issues and Challenges Facing Women in Distance Education. FLEPS 2019 IEEE International Conference on Flexible and Printable Sensors and Systems, Proceedings, 6(1), 146. https://doi.org/10.1016/j.surfcoat.2019.125084

Salih, S. K., \& Taniwall, N. J. (2020). Issues and Challenges of E-Learning System Adoption in a Public University of Afghanistan: A Case Study of Shaikh Zayed. 25(1), 63-69. https://doi.org/10.9790/0837-2501046369

Song, H. H. (2020). Testing and Evaluation System for Cloud Computing Information Security Products. Procedia Computer Science, 166, 84-87. https://doi.org/10.1016/j.procs.2020.02.023

Suadi. (2021). Students' Perceptions of the Use of Zoom and Whatsapp in Elt Amidst Covid19 Pandemic. SALEE: Study of Applied Linguistics and English Education, 2(01 SE-Articles), 51-64. https://doi.org/10.35961/salee.v2i01.212

Sultani, T. (2001). The Current Situation of Basic Education in Afghanistan.

Ta'amneh, M. A. A. A. (2017). The Effect of Using WhatsApp Messenger in Learning English Language among University Students. International Research in Education, 5(1), 143. https://doi.org/10.5296/ire.v5i1.10801

Zhang, D., Zhao, J. L., Zhou, L., \& Nunamaker, J. F. (2004). Can e-learning replace classroom learning?
Communications of the ACM, 47(5), 75-79. https://doi.org/10.1145/986213.986216 